\title{
Expression of the cholecystokinin 2 -receptor in normal human thyroid gland and medullary thyroid carcinoma
}

\author{
Michael Bläker, Andreas de Weerth, Mareike Tometten, Martina Schulz, Wolfgang Höppner ${ }^{1}$, Dorit Arlt ${ }^{1}$, \\ Cuong Hoang- $\mathrm{Vu}^{2}$, Henning Dralle ${ }^{2}$, Harald Terpe ${ }^{3}$, Ludwig Jonas ${ }^{3}$ and Tammo von Schrenck \\ Medizinische Kernklinik und Poliklinik, Universitätsklinikum Hamburg-Eppendorf, Germany, ${ }^{1}$ Institut für Hormon- und Fortpflanzungsforschung, \\ Hamburg, Germany, ${ }^{2}$ Universitätsklinik für Allgemeinchirurgie, Halle, Germany and ${ }^{3}$ Institut für Pathologie, Universität Rostock, Germany \\ (Correspondence should be addressed to M Bläker, Medizinische Kernklinik und Poliklinik, Universitätsklinikum Hamburg-Eppendorf, Martinistraße 52, \\ 20246 Hamburg, Germany; Email: blaeker@uke.uni-hamburg.de)
}

\begin{abstract}
Objective: The cholecystokinin ${ }_{2}$-receptor $\left(\mathrm{CCK}_{2} \mathrm{R}\right)$ promotes secretion and cell growth induced by its ligands cholecystokinin (CCK) and gastrin. The receptor has recently been shown to be expressed in human medullary thyroid carcinomas (MTCs). The objective of this study was to analyze $\mathrm{CCK}_{2} \mathrm{R}$ expression in MTC samples of different tumor stages as well as in non-malignant thyroid tissues.

Design and Methods: Using RT-PCR we investigated 19 MTC samples and TT-cells (a human MTC cell line), as well as samples of normal thyroid. In addition, we performed immunohistochemistry using calcitonin- and $\mathrm{CCK}_{2} \mathrm{R}$-specific antibodies on MTCs and samples of C-cell hyperplasia.

Results: We demonstrate for the first time that $\mathrm{CCK}_{2} \mathrm{R}$ is expressed not only in MTCs but in all samples of normal thyroid tissue. Using immunohistochemistry the receptor could be localized on calcitoninsecreting C-cells. The highest incidence of $\mathrm{CCK}_{2} \mathrm{R}$ expression in MTCs was observed in early-tumor stages, whereas $\mathrm{CCK}_{2} \mathrm{R}$ could not be detected in advanced or metastasized tumors.

Conclusions: The expression of $\mathrm{CCK}_{2} \mathrm{R}$ in C-cells suggests a physiological function for gastrin and/or CCK in the regulation of calcitonin release, presumably related to bone and calcium metabolism. Moreover, these ligands might act as growth factors in MTCs. Efforts in the development of $\mathrm{CCK}_{2} \mathrm{R}$ scintigraphy for the detection of MTC lesions might have to consider a lower incidence of the receptor in advanced tumor stages.
\end{abstract}

European Journal of Endocrinology 146 89-96

\section{Introduction}

The G-protein coupled cholecystokinin ${ }_{2}$-receptor $\left(\mathrm{CCK}_{2} \mathrm{R}\right)$ mediates the functions of two enteroendocrine hormones, cholecystokinin (CCK) and gastrin. Stimulation of $\mathrm{CCK}_{2} \mathrm{R}$ leads to acid secretion as well as cell proliferation within the gastric mucosa (1). In addition, gastrin has been shown to induce growth of a variety of normal as well as malignant gastrointestinal cell types in vitro (2). Furthermore, in several tumor systems an autocrine loop has been proposed between gastrin, secreted by tumor cells, and $\mathrm{CCK}_{2} \mathrm{R}$, expressed on tumor cells $(3-6)$.

In recent years, $\mathrm{CCK}_{2} \mathrm{Rs}$ have been detected in various extraintestinal cell types and tumors $(7,8)$. Based on the well-established proliferative effects of gastrin, $\mathrm{CCK}_{2} \mathrm{Rs}$ might be important promoters of growth in these extraintestinal organs and tumors and therefore might serve as interesting diagnostic and therapeutic targets.

Gastrin pentapeptide (pentagastrin) is a well-known secretagogue in medullary thyroid carcinomas (MTCs), which originate from calcitonin-producing C-cells (9). The increase in calcitonin serum levels after i.v. injection of pentagastrin is widely used as a diagnostic tool in MTCs. In 1996, Reubi \& Waser (10) showed by autoradiography that MTCs express $\mathrm{CCK}_{2} \mathrm{Rs}$ with an incidence of $92 \%$. This report was the first to demonstrate $\mathrm{CCK}_{2} \mathrm{R}$ expression in any kind of thyroid tissue. Subsequently, Amiri-Movasi et al. (11) detected $\mathrm{CCK}_{2} \mathrm{R}$ mRNA in six out of six MTCs. However, it remained unclear whether malignant transformation of C-cells leads to aberrant $\mathrm{CCK}_{2} \mathrm{R}$ expression or whether even in normal thyroid tissue $\mathrm{CCK}_{2} \mathrm{R}$ is expressed. Moreover, there are no available data on the relationship between $\mathrm{CCK}_{2} \mathrm{R}$ expression in MTCs and tumor stage, calcitonin levels and possible underlying mutations of the RET proto-oncogene (12).

The aim of the present study was to analyze $\mathrm{CCK}_{2} \mathrm{R}$ expression in normal thyroid tissues as well as in MTCs by RT-PCR and immunohistochemistry using a $\mathrm{CCK}_{2} \mathrm{R}$-specific antibody. Furthermore, we compared receptor expression with clinical and pathological 
data. In addition, to address the possibility of an autocrine loop, we analyzed expression of the known $\mathrm{CCK}_{2} \mathrm{R}$ ligands, CCK and gastrin, in normal thyroid tissue and MTCs.

\section{Materials and methods}

\section{Patients}

All patients gave informed consent to the study of their tissue samples and clinical data prior to surgery. The study was approved by the local ethics committee.

Patient data corresponding to the investigated MTC samples are summarized in Table 1.

\section{Tissue samples and cells}

After surgical resection, aliquots of tissue samples were immediately frozen in liquid nitrogen and then stored at $-80^{\circ} \mathrm{C}$. Diagnosis of underlying disease was verified by histological examination. The tissue samples investigated were 19 MTCs and two samples of normal thyroid gland removed during surgery for non-toxic goiter ('goiter 1', 'goiter 2'). In addition, commercially available pooled thyroid cDNA (Clontech, Heidelberg, Germany) was studied for the presence of $\mathrm{CCK}_{2} \mathrm{R}$ transcripts. Tissue samples of normal human stomach and normal human colon served as positive and negative controls respectively. TT cells were purchased from the American Type Culture Collection (Rockville, MD, USA) and cultured in Ham's F12 medium, supplemented with $2 \mathrm{mmol} / \mathrm{l}$ glutamine, $1 \%$ non-essential amino acids, $1 \%$ sodium pyruvate and $10 \%$ fetal calf serum (Gibco
Life Technologies, Eggenstein, Germany) at $37^{\circ} \mathrm{C}$. When grown to confluence, cells were trypsinized (trypsin $0.05 \%$, EDTA $0.02 \%$ ) and RNA was extracted as described below.

\section{Pentagastrin stimulation test}

Pentagastrin (Cambridge Laboratories, Cambridge, Cambs, UK) (0.5 U/kg body weight) was injected i.v. Blood samples were drawn 2 min before, immediately before, $2 \mathrm{~min}$ after and $5 \mathrm{~min}$ after pentagastrin injection.

\section{RT-PCR}

Total RNA was extracted from the tissue samples or TT cells using RNAzol (WAK-Chemie, Bad Homburg, Germany) according to the protocol supplied by the manufacturer. RNA was then treated with DNase I for $15 \mathrm{~min}$ at $37^{\circ} \mathrm{C}$. First-strand cDNA was transcribed from $2 \mu \mathrm{g}$ total RNA. Three hundred nanograms of cDNA were used for PCR using the following primers: $\mathrm{CCK}_{2} \mathrm{R}$ forward: 5'-CGT GTG CTG CAG TGC GTG CA-3', $\mathrm{CCK}_{2} \mathrm{R}$ reverse: $5^{\prime}$-GGT GGT GTA GCT AAG CCT GG-3'; $\beta$-actin forward: $5^{\prime}$-ATC TGG CAC CAC ACC TTC TAC A-3', $\beta$-actin reverse: $5^{\prime}$-GCT CAT TGC CAA TGG TGA TGA C-3'; gastrin forward: 5'-CAG CGA CTA TGT GTG TAT GT-3', gastrin reverse: $5^{\prime}$-TTC TTG GAC GGG TCT GCC AC-3'; CCK forward: 5'-CCA AAA GCC ATG AAC AGC GGC G-3', CCK reverse: 5'-ATC CAT CCA GCC CAT GTA GTC C-3'. The PCR conditions were: $5 \mathrm{~min}$ at $95^{\circ} \mathrm{C}$ followed by 35 cycles for $1 \mathrm{~min}$ at $94^{\circ} \mathrm{C}, 1 \mathrm{~min}$

Table 1 Patient data, tumor stage, calcitonin levels, RET mutation and $\mathrm{CCK}_{2} \mathrm{R}$ status in the investigated MTC tumor population. Note that pathological data according to the T, N, M classification system were not available for all investigated tumor samples.

\begin{tabular}{|c|c|c|c|c|c|c|c|}
\hline Sample & Gender & Age & T N M & $\begin{array}{l}\text { Calcitonin } \\
(\mathrm{ng} / \mathrm{l})\end{array}$ & $\begin{array}{l}\text { RET mutation } \\
\text { (codon) }\end{array}$ & Remarks & $\mathrm{CCK}_{2} \mathrm{R}$ expression \\
\hline 1 & $\mathrm{~F}$ & 48 & 200 & 1000 & 918 & - & Positive \\
\hline 2 & M & 56 & $20-$ & - & - & - & Positive \\
\hline 3 & $M$ & 67 & 411 & 1033 & - & - & Negative \\
\hline 4 & M & 53 & 110 & 3330 & - & - & Positive \\
\hline 5 & M & 60 & $4-1$ & 1802 & 918 & - & Negative \\
\hline 6 & $\mathrm{~F}$ & 62 & --- & - & - & - & Positive \\
\hline 7 & $\mathrm{~F}$ & 56 & $2--$ & 483 & - & - & Negative \\
\hline 8 & M & 56 & $-1-$ & 3774 & 918 & - & Positive \\
\hline 9 & $\mathrm{~F}$ & 63 & $21-$ & 214 & - & - & Positive \\
\hline 10 & $\mathrm{~F}$ & 17 & $21-$ & 2810 & - & MEN-2 & Negative \\
\hline 11 & $\mathrm{~F}$ & 33 & $31-$ & 2145 & - & - & Negative \\
\hline 12 & M & 35 & $20-$ & 3262 & - & - & Positive \\
\hline 13 & $\mathrm{~F}$ & 47 & 110 & 807 & 918 & - & Positive \\
\hline 14 & $\mathrm{~F}$ & 65 & --- & 1350 & - & - & Positive \\
\hline 15 & $\mathrm{~F}$ & 63 & -11 & - & - & - & Negative \\
\hline 16 & $\mathrm{~F}$ & 71 & 200 & - & - & - & Positive \\
\hline 17 & $\mathrm{~F}$ & 45 & 410 & - & 918 & - & Negative \\
\hline 18 & M & 57 & $31-$ & 900 & - & PGT negative & Negative \\
\hline 19 & $\mathrm{M}$ & 56 & 200 & 238 & 634 & MEN-2; PGT positive & Positive \\
\hline
\end{tabular}

PGT, pentagastrin test. 
at $60{ }^{\circ} \mathrm{C}$ and $2 \mathrm{~min}$ at $72^{\circ} \mathrm{C}$, followed by $10 \mathrm{~min}$ at $72{ }^{\circ} \mathrm{C}$. Aliquots $(5 \mu \mathrm{l})$ of the PCR products were analyzed on $1.2 \%$ agarose gels. Specificity of $\mathrm{CCK}_{2} \mathrm{R}$ PCR products was confirmed by restriction endonuclease digestion.

\section{Detection of RET oncogene mutations}

For the detection of mutations in codon 918 (exon 16) of the RET proto-oncogene, RNA was extracted from sporadic MTCs by the RNAzol method and transcribed into cDNA (see above). PCR was performed using the following primers: exon 16 forward: 5'-AGG GAT AGG GCC TGG GCT TC-3', exon 16 reverse: 5'-TAA CCT CCA CCC CAA GAG AG-3'. PCR conditions: $1 \mathrm{~min}$ at $96{ }^{\circ} \mathrm{C}$ followed by 35 cycles for $1 \mathrm{~min}$ at $94{ }^{\circ} \mathrm{C}, 30 \mathrm{~s}$ at $65^{\circ} \mathrm{C}$ and $45 \mathrm{~s}$ at $72^{\circ} \mathrm{C}$. PCR products were purified using a Qiagen purification kit (Qiagen, Hilden, Germany) and sequence analysis was performed using an automated DNA sequencer (Applied Biosystems, Foster City, CA, USA).

\section{Immunohistochemistry}

Paraffin sections of human C-cell hyperplasia or MTCs of about $5 \mu \mathrm{m}$ thickness were deparaffinized in xylene, rehydrated and washed in PBS. The sections were incubated with $3 \% \mathrm{H}_{2} \mathrm{O}_{2}$ for 20 min to block endogenous peroxidase activity followed by incubation in 5\% swine normal serum. The sections were incubated with specific primary antibodies (anti-calcitonin IgG from rabbit (DAKO A0576; DAKO, Hamburg, Germany); anti-human $\mathrm{CCK}_{2} \mathrm{R}$ IgY from chicken $\left.(13,14)\right)$ for $48 \mathrm{~h}$ at $4{ }^{\circ} \mathrm{C}$ in a moist chamber at dilutions between 1:30 and 1:1280. After washing three times with PBS, the sections were incubated with anti-rabbit IgG from swine (DAKO) or anti-chicken IgY (Dianova, Hamburg, Germany) at a dilution of 1:50 for $1 \mathrm{~h}$ at $22^{\circ} \mathrm{C}$. After washing in PBS three times, the sections were incubated with peroxidase-anti-peroxidase complex and peroxidase-conjugated streptavidin (Dianova) respectively, for $1 \mathrm{~h}$ at a dilution of $1: 50$ at $22^{\circ} \mathrm{C}$. After washing, the horseradish peroxidase activity was detected by substrate solution, containing diaminobenzidine, $0.05 \mathrm{~mol} / \mathrm{l}$ Tris-HCl buffer $(\mathrm{pH} 7.6)$ and $0.01 \% \mathrm{H}_{2} \mathrm{O}_{2}$. Finally, the sections were counterstained with acidic haemalaun and, after embedding, were investigated by light microscopy.

\section{Results}

\section{RT-PCR studies}

Using primers specific for human $\beta$-actin cDNA, a PCR product of the expected size was amplified in all investigated samples. A $729 \mathrm{bp} \mathrm{CCK}_{2} \mathrm{R}$-specific PCR product was amplified from the following samples: normal human stomach cDNA, commercially available pooled cDNA from normal human thyroid, normal thyroid tissue of two patients who underwent surgery for nontoxic goiter ('goiter 1', 'goiter 2'), TT-cells (a human MTC cell line), and 11 out of 19 MTC samples. No $\mathrm{CCK}_{2-}$ R-specific PCR product could be detected in eight MTC samples (Figs 1 and 2; Table 1). Expression of gastrin was not detected in any of the investigated samples (data not shown). CCK expression was detected in normal thyroid cDNA as well as in one thyroid sample from a patient with non-toxic goiter but was not detected in any of the MTC samples (Fig. 1).

\section{Immunohistochemistry}

In addition to RT-PCR, $\mathrm{CCK}_{2} \mathrm{R}$ expression was detected in human MTCs by immunohistochemical analysis. Using a $\mathrm{CCK}_{2} \mathrm{R}$-specific antibody, directed against the extracellular N-terminal portion of the receptor protein, receptor expression was visualized in three out of five investigated MTCs (Fig. 3). In addition to MTCs, $\mathrm{CCK}_{2} \mathrm{R}$ immunoreactivity was observed in C-cell hyperplasia, which is defined as an increase in the number of non-malignant C-cells. Immunohistochemistry using antibodies against calcitonin and $\mathrm{CCK}_{2} \mathrm{R}$ demonstrated that only C-cells express $\mathrm{CCK}_{2} \mathrm{R}$ (Fig. 4).

\section{Comparison of clinical, molecular and pathological data}

Table 1 summarizes the available clinical and pathological data in the MTC patients. All patients had elevated baseline calcitonin levels. Only in two patients were results of pentagastrin tests available. One test was negative (patient 18) and the corresponding tumor sample did not show $\mathrm{CCK}_{2} \mathrm{R}$ expression (Fig. 1a). The positive pentagastrin test (patient 19) is shown in Fig. 1b. In the corresponding tumor sample, $\mathrm{CCK}_{2} \mathrm{R}$ was detected (Fig. 1a). This patient and patient 10 had MTC as part of the multiple endocrine neoplasia type 2 (MEN-2) syndrome. All other MTCs were sporadic tumors.

Activating mutations of the RET proto-oncogene have been shown to play a key role in the pathogenesis of MEN-2 and MTC (12). Consistent with previous reports (15), we found mutations of codon 918 within exon 16 of the RET gene in 30\% of the sporadic MTCs investigated. No correlation was found between RET mutations and $\mathrm{CCK}_{2} \mathrm{R}$ expression.

Comparison with pathological data revealed that detectable $\mathrm{CCK}_{2} \mathrm{R}$ expression was restricted to $\mathrm{T} 1$ - and T2-stage tumors which did not show metastases. In contrast, in none of the further advanced tumor stages (T3, T4, Mx) was $\mathrm{CCK}_{2} \mathrm{R}$ expression detected (Fig. 2).

\section{Discussion}

$\mathrm{CCK}_{2} \mathrm{R}$ was originally cloned from parietal cells $(16,17)$ and later found to be identical to the CCK receptor in 
a)

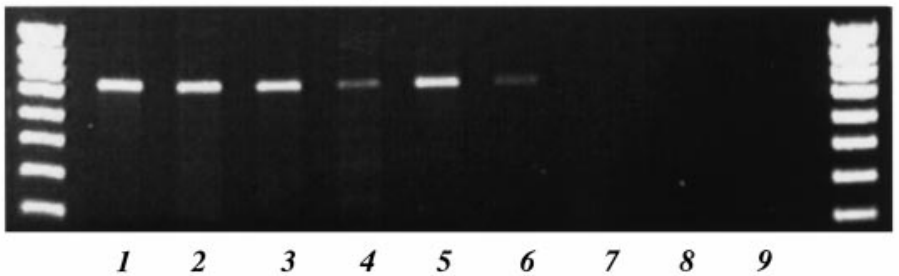

\section{CCK2R}

lane-number

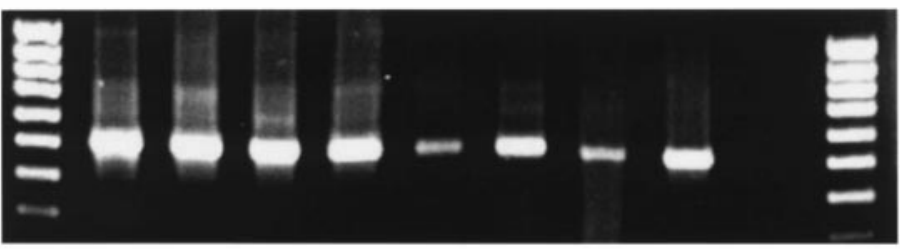

\section{B-actin}

b)

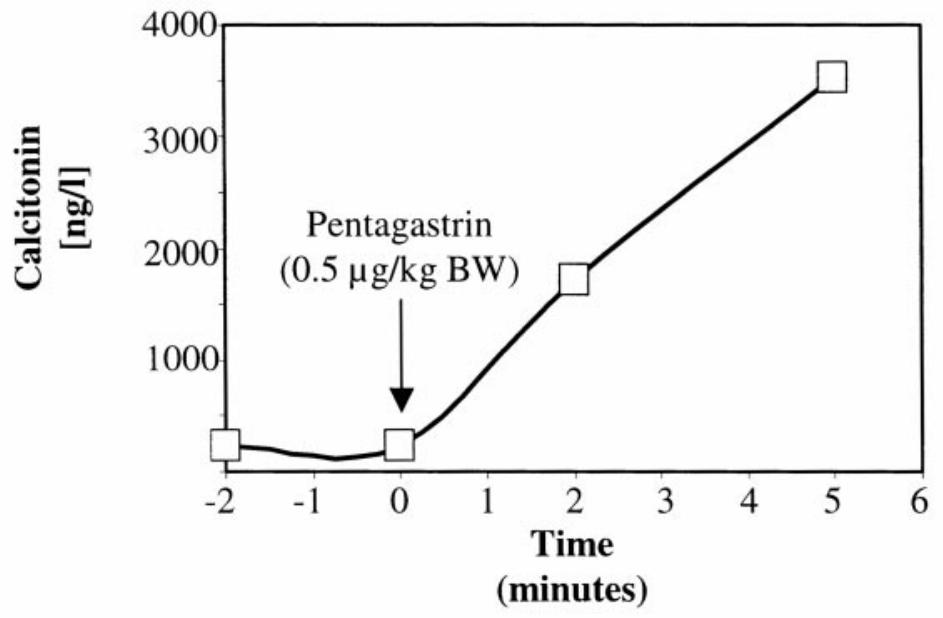

\section{Patient 19}

(* fig. 1a))

c)
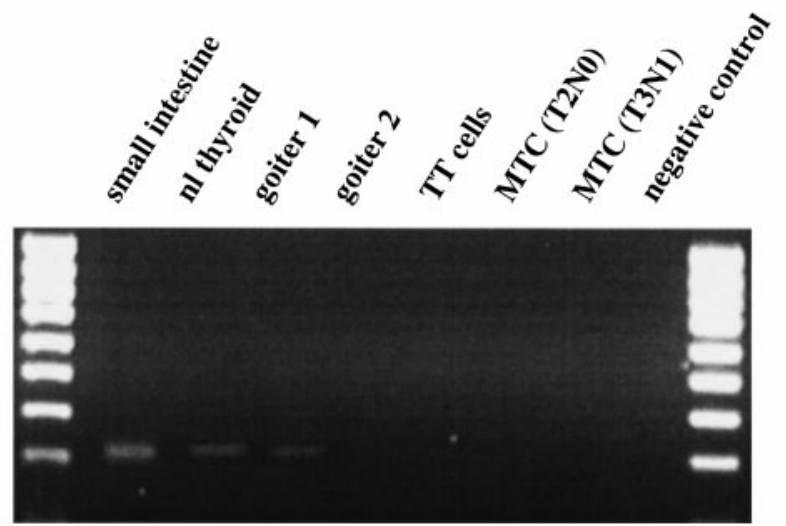

CCK

Figure 1 Detection of $\mathrm{CCK}_{2} \mathrm{R}$ expression. (a) $\mathrm{CCK}_{2} \mathrm{R}$ is expressed in human stomach as well as in all samples of normal thyroid tissue (lanes 2-4, upper panel). $\mathrm{CCK}_{2} \mathrm{R}$ expression is also detectable in TT-cells and MTCs. Lane 6 represents the tumor sample from patient 19 (see Table 1). The asterisk indicates that the pentagastrin test shown in (b) corresponds to the result shown in this lane. Not all MTCs express $\mathrm{CCK}_{2} \mathrm{R}$; lane 7 represents the tumor sample from patient 18 (see Table 1) in which no $\mathrm{CCK}_{2} \mathrm{R}$ expression is detected. As expected, $\mathrm{CCK}_{2} \mathrm{R}$ is not expressed in the colon (lane 8). The housekeeping gene $\beta$-actin is expressed in all investigated samples (lower panel of (a)). (b) Positive pentagastrin stimulation test in patient 19 (a) (see Table 1). Pentagastrin was injected i.v. (arrow). Calcitonin serum levels rose from 238 to $1717 \mathrm{ng} / \mathrm{l}$ after $2 \mathrm{~min}$ and to $3523 \mathrm{ng} / \mathrm{l}$ after $5 \mathrm{~min}$. The pentagastrin test is considered positive if calcitonin levels rise $>200 \mathrm{ng} / \mathrm{l}$ after pentagastrin injection. (c) Detection of CCK expression. CCK mRNA is detectable in samples of small intestine and normal thyroid but not in MTC.

www.eje.org 


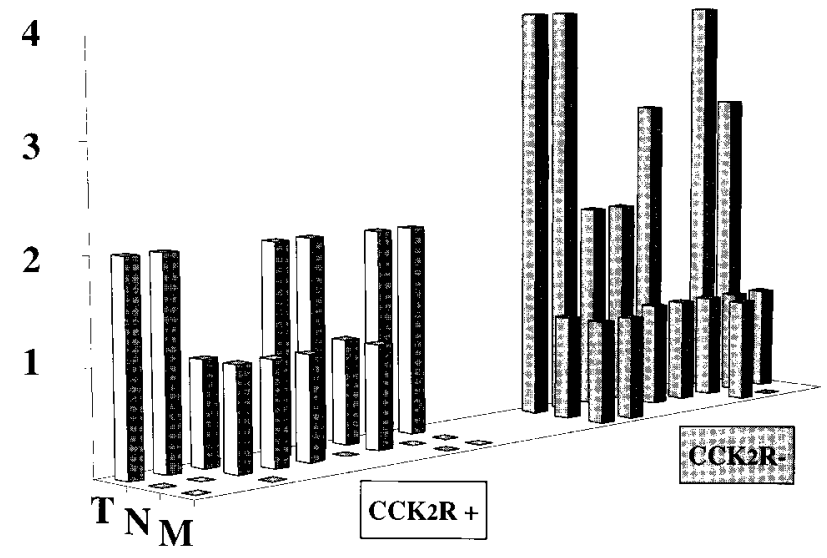

Figure 2 Comparison of MTCs which do express (white bars) and do not express (gray bars) $\mathrm{CCK}_{2} \mathrm{R}$. In the investigated tumor population for which pathological data according to the $T, N, M$ classification were available, $\mathrm{CCK}_{2} \mathrm{R}$-positive samples are smaller in size and have not metastasized to other organs, whereas the group of $\mathrm{CCK}_{2} \mathrm{R}$-negative tumors includes large and metastasized tumors. brain (18). In recent years, it has become apparent that expression of this receptor subtype is more widespread than initially expected. Using molecular detection techniques as well as immunohistochemistry and autoradiography, expression of $\mathrm{CCK}_{2} \mathrm{R}$ has been detected in pancreatic acinar cells, monocytes, $\mathrm{T}$ lymphocytes, kidney, and in a wide variety of human tumors $(7,8,19)$. In most of these tumors $\mathrm{CCK}_{2} \mathrm{R}$ expression occurs aberrantly, possibly related to dedifferentiation of the tumor cells.

Reubi \& Waser (10) reported the expression of $\mathrm{CCK}_{2}$ Rs with very high incidence in human MTCs but did not find expression of the receptor in normal thyroid tissue using autoradiography. We now demonstrate by RT-PCR that $\mathrm{CCK}_{2} \mathrm{R}$ is expressed not only in MTCs but also in all investigated samples of non-malignant thyroid tissues. This difference from the report by Reubi \& Waser is probably explained by the higher sensitivity of the RT-PCR method. Moreover, in normal thyroid glands, C-cells are found singularly or in groups of
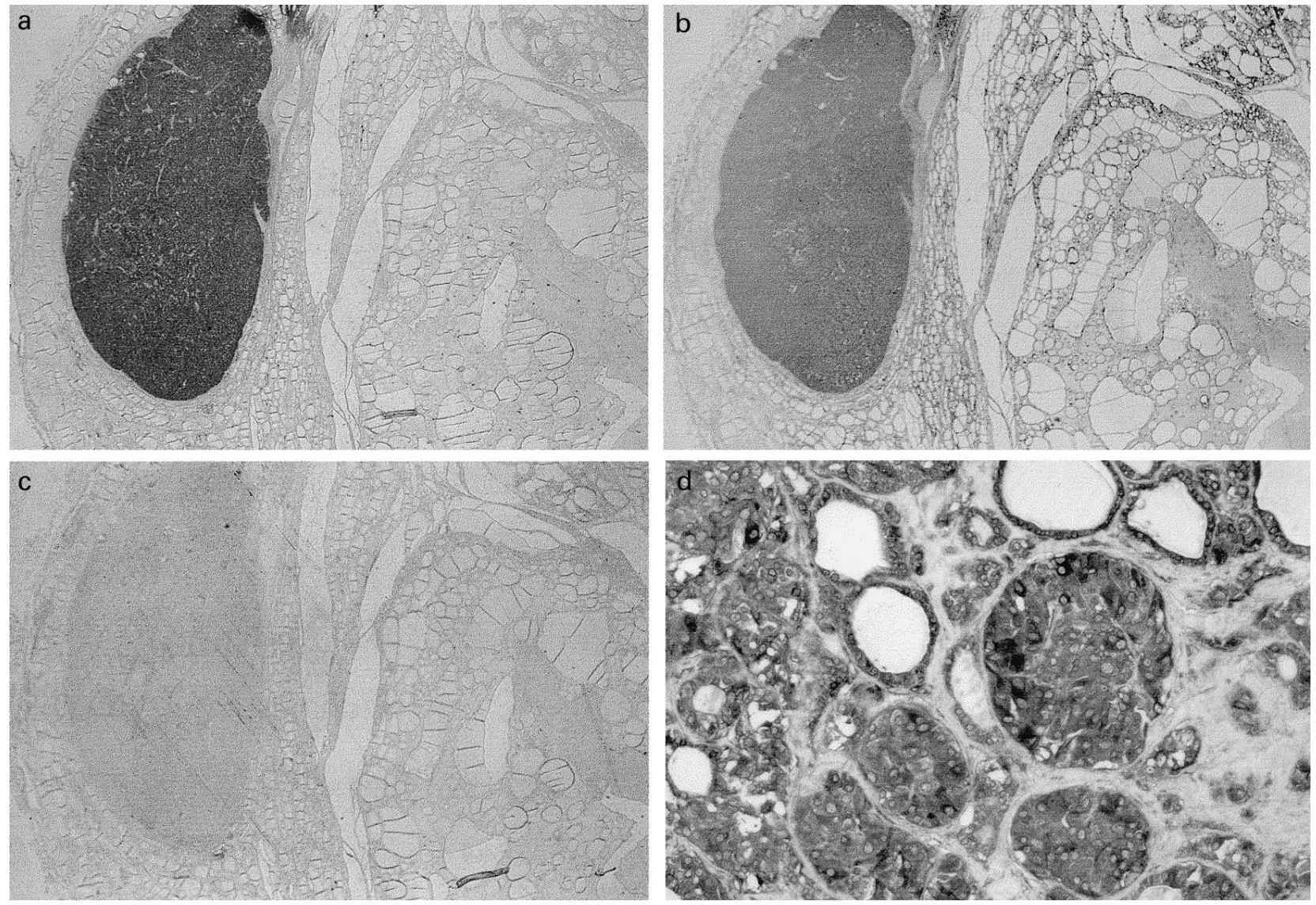

Figure 3 Immunohistochemical detection of $\mathrm{CCK}_{2} \mathrm{R}$ in MTC. (a) Staining of tumor tissue with antibodies against calcitonin (magnification $\times 3.2$ ). (b) Adjacent section showing immunoreactivity using a $\mathrm{CCK}_{2} \mathrm{R}$-specific antibody (magnification $\times 3.2$ ). (c) Adjacent section after incubation with IgY antibodies which were preabsorbed using the antigen (magnification $\times 3.2)$. (d) High power magnification $(\times 40)$ of $\mathrm{CCK}_{2} \mathrm{R}$-positive tumor cells. 

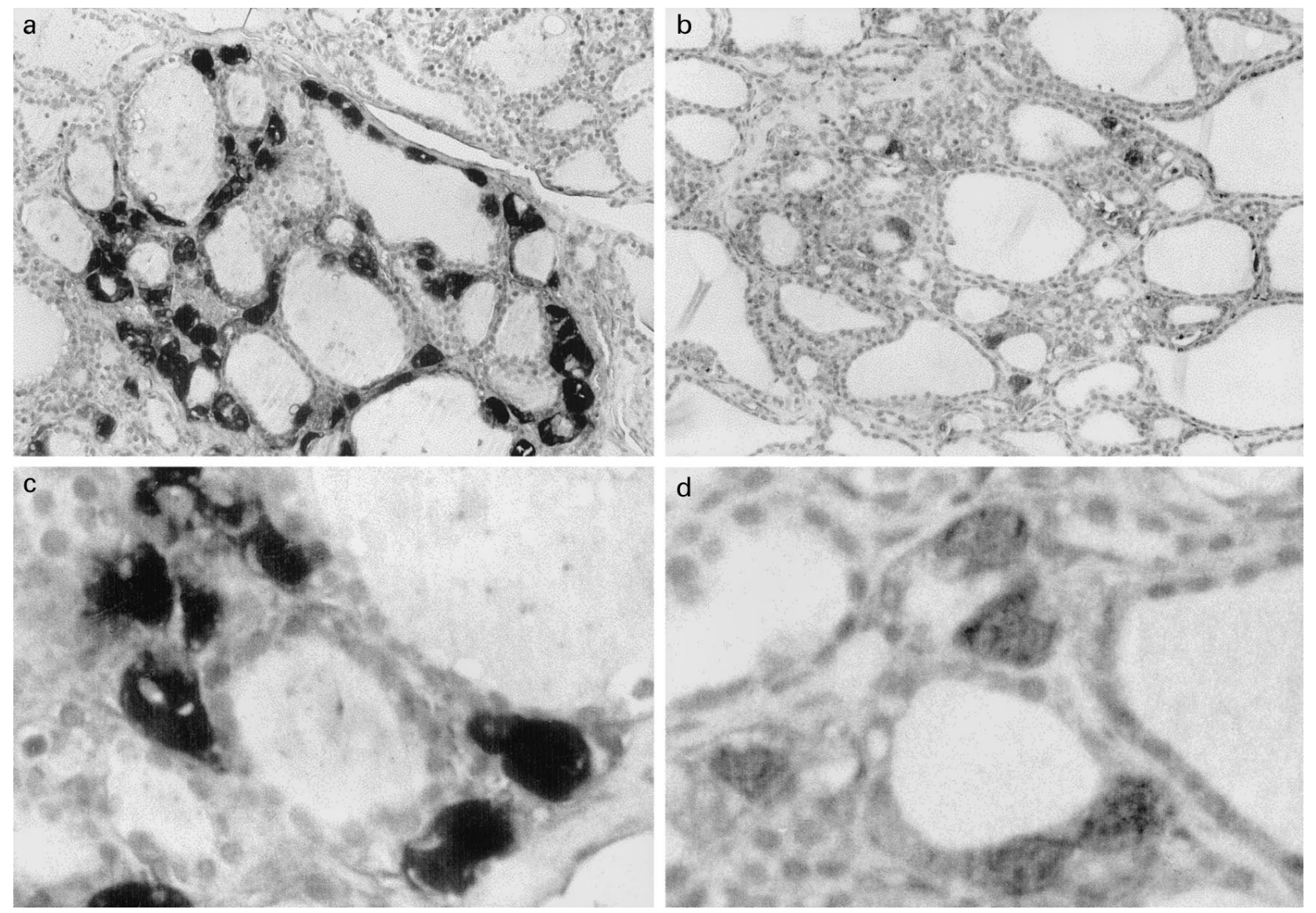

Figure 4 Immunohistochemical detection of $\mathrm{CCK}_{2} \mathrm{R}$ in C-cells. (a) Immunoreactivity against calcitonin in a sample of benign $\mathrm{C}$-cell hyperplasia (magnification $\times 25$ ). (b) Immunohistochemical detection of $\mathrm{CCK}_{2} \mathrm{R}$ in C-cells (magnification $\left.\times 25\right)$. (c) High power magnification $(\times 80)$ of calcitonin reactivity in C-cells. (d) High power magnification $(\times 80)$ of $\mathrm{CCK}_{2}$ R-reactivity in C-cells.

two to five cells and are located primarily in the dorsolateral part of the organ. Therefore, in microscopic studies these cells might be missed. Based on these considerations we used samples of non-malignant C-cell hyperplasia for immunohistochemical studies and were able to show for the first time that $\mathrm{CCK}_{2} \mathrm{R}$ is expressed in normal C-cells.

The detection of $\mathrm{CCK}_{2} \mathrm{R}$ expression supports the concept of a physiological function of gastrin and/or CCK in C-cells. Thirty years ago, it was shown for the first time that both hormones induce calcitonin secretion (20, 21). The physiological and pathophysiological relevance of these early findings has been discussed controversially $(22,23)$. It is well known that gastrectomy, including the removal of the antrum, where gastrinproducing G-cells are located, leads to a significant reduction in bone density and alterations in calcium metabolism $(24,25)$. In fact, it has been shown in gastrectomized patients that in response to a meal, increases in calcitonin levels were significantly smaller than in control groups, most likely based on impaired gastrin secretion (23). Animal models have confirmed the importance of gastrin for calcium and bone homeostasis; in rats, antrectomy and total gastrectomy, both resulting in hypogastrinemia, lead to osteopenia and reduction in bone mineral content $(26,27)$. However, a direct positive correlation between gastrin levels and calcitonin levels could be established neither in these models nor in rats after fundectomy and reflectory hypergastrinemia (28). One explanation might be that gastrin leads to pulsatile calcitonin release in response to enteral stimulation rather than influencing basal secretion of calcitonin from C-cells. In addition, CCK might compensate in part for the lack of gastrin after gastrectomy, albeit not to a degree that prevents osteopenia. The detection of $\mathrm{CCK}_{2} \mathrm{R}$ on C-cells reported in this study clearly supports the concept of an interrelationship among calcemic hormones and gastrointestinal hormones (29).

Given the physiological expression of $\mathrm{CCK}_{2} \mathrm{R}$ in C-cells we speculate that the pentagastrin stimulation test, which is used as a diagnostic tool, reflects the vast increase in the number of C-cells in MTCs rather than a specific expression of the receptor in malignant vs 
non-malignant cells. This view is supported by the fact that the pentagastrin test has been shown to be positive in cases of benign C-cell hyperplasia (30, 31). Furthermore, pentagastrin injection has been shown to cause a slight yet significant increase in calcitonin serum levels in normal subjects (32). All patients investigated in our study already had substantially elevated baseline calcitonin levels (Table 1). Therefore, in most cases pentagastrin stimulation was not performed. Only for two patients were the results of pentagastrin tests available. As expected, $\mathrm{CCK}_{2} \mathrm{R}$ expression was detectable in the tumor sample corresponding to the positive result, whereas $\mathrm{CCK}_{2} \mathrm{R}$ expression was not detected in the sample from the patient with the negative pentagastrin test (Table 1, Fig. 1). Although performed only in a limited number of patients, the pentagastrin test appears to correlate with $\mathrm{CCK}_{2} \mathrm{R}$ expression in MTCs.

In contrast to multiple other tumors, in which $\mathrm{CCK}_{2} \mathrm{R}$ expression most likely occurs due to loss of differentiation of the tumor cells, the expression of $\mathrm{CCK}_{2} \mathrm{R}$ in MTCs appears to be related to maintained differentiation of the malignant C-cell. Thus, $\mathrm{CCK}_{2} \mathrm{Rs}$ are found in almost all early-stage tumors ( $\mathrm{T} 1$ and $\mathrm{T} 2$ stages) while further growth and potential loss of cell differentiation, i.e. in $\mathrm{T} 3$ and $\mathrm{T} 4$ tumors and metastasized tumors, might be associated with a loss of receptor expression. This phenomenon has also been reported for somatostatin receptors in MTCs $(33,34)$. The conclusion that $\mathrm{CCK}_{2} \mathrm{R}$ expression in MTCs depends on the degree of tumor differentiation is further supported by a recent report by Kwekkebom et al. (35). In that study, aimed at visualization of $\mathrm{CCK}_{2} \mathrm{Rs}$ on MTCs in vivo using radiolabeled CCK-8 (which has high affinity for $\mathrm{CCK}_{2} \mathrm{R}$ ), scintigraphic detection of known tumor metastases could not be achieved in one of two patients. Autoradiographic analysis of one of the respective liver lesions revealed the absence of $\mathrm{CCK}_{2} \mathrm{R}$ expression in the investigated sample; in addition, the pentagastrin test in the patient remained negative (35). Therefore, in the light of encouraging technical results (35-37), $\mathrm{CCK}_{2} \mathrm{R}$ scintigraphy for visualization of MTC lesions might be more useful in earlier stages of the disease than in faradvanced metastasized tumors. However, studies with larger numbers of patients comparing clinical, scintigraphic and molecular data are required to reach a final conclusion.

Gastrin is a well-known major growth factor for enterochromaffin-like (ECL) cells in the stomach (38). In mouse models, lack of gastrin or its receptor leads to marked reduction in the number of ECL cells $(39,40)$. In addition, differentiation and maturation of ECL cells appears to be highly dependent on gastrin (39). In conditions associated with hypergastrinemia ECL cells become hyperplastic and may ultimately transform into malignant carcinoids (38). Like ECL cells, C-cells are neuroendocrine cells and both cell types share several histomorphological and biological features. Therefore, in analogy to ECL cells, C-cells might become hyperplastic in states of hypergastrinemia either due to disease (pernicious anemia, Zollinger-Ellison syndrome) or due to pharmacotherapy (e.g. proton pump inhibitors). Moreover, gastrin might act as a growth factor in MTCs.

In several tumor models, an autocrine loop involving gastrin and $\mathrm{CCK}_{2} \mathrm{R}$ has been proposed, based on the coexpression of both the ligand and the receptor in these tumors $(3-6)$. Our data do not indicate that such an autocrine loop exists in MTCs. Neither of the two $\mathrm{CCK}_{2} \mathrm{R}$ ligands, gastrin or $\mathrm{CCK}$, is expressed in MTCs. In contrast, CCK mRNA, together with $\mathrm{CCK}_{2} \mathrm{R}$ mRNA, is detectable in normal thyroid tissue and in one sample of goiter (Fig. 1c). CCK has been identified as a secretory product of rat MTC cells $(41,42)$. It is not known whether CCK is expressed in normal rat thyroid. Given the fact that we found CCK expression only in two samples of non-malignant human thyroid tissue while in none of the tumor samples was CCK detectable, one might speculate that $\mathrm{CCK}$ and $\mathrm{CCK}_{2} \mathrm{R}$ are involved in an autocrine loop which contributes to normal C-cell function.

In summary, we have shown for the first time that $\mathrm{CCK}_{2} \mathrm{R}$ is expressed in normal thyroid tissue, specifically in C-cells. These findings support previous reports which suggest that $\mathrm{CCK}_{2} \mathrm{R}$ ligands might play a physiological role in calcitonin-related bone and calcium metabolism. It appears that in MTC the incidence of $\mathrm{CCK}_{2} \mathrm{R}$ is particularly high in small primary tumors. $\mathrm{CCK}_{2} \mathrm{R}$ might therefore serve as a marker of differentiation in MTCs and might be an interesting diagnostic and therapeutic target.

\section{Acknowledgements}

We thank Prof. Sören Schröder, Prof. Jochen Kußmann and Dr Jürgen Kahl for providing tissue samples. This work was supported by the Deutsche Forschungsgemeinschaft.

\section{References}

1 Walsh JH. Gastrin. In Gut Peptides, pp 75-121. Eds JH Walsh \& GJ Dockray. New York: Raven Press, 1994.

2 Baldwin GS. The role of gastrin and cholecystokinin in normal and neoplastic gastrointestinal growth. Journal of Gastroenterology and Hepatology $199510215-232$.

3 Goetze JP, Nielsen FC, Burcharth F \& Rehfeld JF. Closing the gastrin loop in pancreatic carcinoma: coexpression of gastrin and its receptor in solid human pancreatic adenocarcinoma. Cancer $2000882487-2494$.

4 Iwata N, Murayama T, Matsumori Y, Ito M, Nagata A, Taniguchi T et al. Autocrine loop through cholecystokinin-B/gastrin receptors involved in growth of human leukemia cells. Blood $1996 \mathbf{8 8}$ 2683-2689.

5 McWilliams DF, Watson SA, Crosbee DM, Michaeli D \& Seth R. Coexpression of gastrin and gastrin receptors (CCK-B and delta CCK-B) in gastrointestinal tumour cell lines. Gut $1998 \mathbf{4 2}$ 795-798. 
6 Baldwin GS \& Shulkes A. Gastrin, gastrin receptors and colorectal carcinoma. Gut $1998 \mathbf{4 2} 581-584$.

7 Noble F, Wank SA, Crawley JN, Bradwejn J, Seroogy KB, Hamon M et al. International Union of Pharmacology XXI. Structure, distribution, and functions of cholecystokinin receptors. Pharmacological Reviews 199951 745-781.

8 von Schrenck T, de Weerth A, Bechtel S, Eschenhagen T, Weil J, Wolf $\mathrm{G}$ et al. Evidence for $\operatorname{CCK}(\mathrm{B})$ receptors in the guinea-pig kidney: localization and characterization by $\left[{ }^{125} \mathrm{I}\right]$ gastrin binding studies and by RT-PCR. Naunyn Schmiedeberg's Archives of Pharmacology $1998358287-292$.

9 Giuffrida D \& Gharib H. Current diagnosis and management of medullary thyroid carcinoma. Annals of Oncology 19989 695-701.

10 Reubi JC \& Waser B. Unexpected high incidence of cholecystokinin-B/gastrin receptors in human medullary thyroid carcinomas. International Journal of Cancer $1996 \mathbf{6 7} 644-647$.

11 Amiri-Mosavi A, Ahlman H, Tisell LE, Wangberg B, Kolby L, ForssellAronsson E et al. Expression of cholecystokinin-B/gastrin receptors in medullary thyroid cancer. European Journal of Surgery $1999165628-631$

12 Eng C. Seminars in medicine of the Beth Israel Hospital Boston. The RET proto-oncogene in multiple endocrine neoplasia type 2 and Hirschsprung's disease. New England Journal of Medicine $1996335943-951$.

13 de Weerth A, Jonas L, Schade R, Schoneberg T, Wolf G, Pace A et al Gastrin/cholecystokinin type B receptors in the kidney: molecular, pharmacological, functional characterization, and localization. European Journal of Clinical Investigation 199828 592-601.

14 von Schrenck T, Ahrens M, de Weerth A, Bobrowski C, Wolf G, Jonas L et al. CCKB/gastrin receptors mediate changes in sodium and potassium absorption in the isolated perfused rat kidney. Kidney International $2000 \mathbf{5 8}$ 995-1003.

15 Pacini F, Elisei R, Romei C \& Pinchera A. RET proto-oncogene mutations in thyroid carcinomas: clinical relevance. Journal of Endocrinological Investigation 200023 328-338.

16 Kopin AS, Lee YM, McBride EW, Miller LJ, Lu M, Lin HY et al. Expression,cloning and characterization of the canine parietal cell gastrin receptor. PNAS 199289 3605-3609.

17 Wank SA, Pisegna JR \& de Weerth A. Brain and gastrointestinal cholecystokinin receptor family: structure and function. PNAS $1992898691-8695$.

18 Lee YM, Beinborn M, McBride EW, Lu M, Kolakowski LF Jr \& Kopin AS. The human brain cholecystokinin-B/gastrin receptor. Cloning and characterization. Journal of Biological Chemistry 1993268 8164-8169.

19 Reubi JC, Schaer JC \& Waser B. Cholecystokinin (CCK)-A. and CCK-B/gastrin receptors in human tumors. Cancer Research $1997571377-1386$.

20 Care AD, Bruce JB, Boelkins J, Kenny AD, Conaway H \& Anast CS. Role of pancreozymin-cholecystokinin and structurally related compounds as calcitonin secretogogues. Endocrinology 197189 262-271.

21 Cooper CW, Schwesinger WH, Mahgoub AM \& Ontjes DA. Thyrocalcitonin: stimulation of secretion by pentagastrin. Science 1971 $1721238-1240$

22 Heynen G, Brassine A, Daubresse JC, Ligny G, Kanis JA, Gaspar S et al. Lack of clinical and physiological relationship between gastrin and calcitonin in man. European Journal of Clinical Investigation $198111331-335$.

23 Filipponi P, Gregorio F, Cristallini S, Mannarelli C, Blass A, Scarponi $\mathrm{AM}$ et al. Partial gastrectomy and mineral metabolism: effects on gastrin-calcitonin release. Bone and Mineral 199011 199-208.

24 Klein KB, Orwoll ES, Lieberman DA, Meier DE, McClung MR \& Parfitt AM. Metabolic bone disease in asymptomatic men after partial gastrectomy with Billroth II anastomosis. Gastroenterology $198792608-616$

25 Bisballe S, Eriksen EF, Melsen F, Mosekilde L, Sorensen OH \& Hessov I. Osteopenia and osteomalacia after gastrectomy: interrelations between biochemical markers of bone remodelling, vitamin D metabolites, and bone histomorphometry. Gut 199132 1303-1307.
26 Fries W, Rumenapf G \& Schwille PO. Disturbances of mineral and bone metabolism following gastric antrectomy in the rat. Bone and Mineral $199219245-256$.

27 Rumenapf G, Schwille PO, Erben RG, Schreiber M, Fries W, Schmiedl A et al. Osteopenia following total gastrectomy in the rat - state of mineral metabolism and bone histomorphometry. European Surgical Research 199729 209-221.

28 Rumenapf G, Schwille PO, Erben RG, Schreiber M, Berge B, Fries W et al. Gastric fundectomy in the rat: effects on mineral and bone metabolism, with emphasis on the gastrin-calcitonin-parathyroid hormone-vitamin D axis. Calcified Tissue International 199863 433-441.

29 Cooper CW, Bolman RMD, Linehan WM \& Wells SA Jr. Interrelationships between calcium, calcemic hormones and gastrointestinal hormones. Recent Progress in Hormone Research 1978 $34259-283$.

30 Libbey NP, Nowakowski KJ \& Tucci JR. C-cell hyperplasia of the thyroid in a patient with goitrous hypothyroidism and Hashimoto's thyroiditis. American Journal of Surgical Pathology 1989 $1371-77$.

31 Marsh DJ, McDowall D, Hyland VJ, Andrew SD, Schnitzler M, Gaskin EL et al. The identification of false positive responses to the pentagastrin stimulation test in RET mutation negative members of MEN 2A families. Clinical Endocrinology $1996 \mathbf{4 4} 213-220$.

32 Owyang C, Heath HD, Sizemore GW \& Go VL. Comparison of the effects of pentagastrin and meal-stimulated gastrin on plasma calcitonin in normal man. American Journal of Digestive Diseases $1978231084-1088$.

33 Reubi JC, Chayvialle JA, Franc B, Cohen R, Calmettes C \& Modigliani E. Somatostatin receptors and somatostatin content in medullary thyroid carcinomas. Laboratory Investigation 1991 $64567-573$.

34 Kwekkeboom DJ, Reubi JC, Lamberts SW, Bruining HA, Mulder $\mathrm{AH}$, Oei $\mathrm{HY}$ et al. In vivo somatostatin receptor imaging in medullary thyroid carcinoma. Journal of Clinical Endocrinology and Metabolism 199376 1413-1417.

35 Kwekkeboom DJ, Bakker WH, Kooij PP, Erion J, Srinivasan A, de Jong $\mathrm{M}$ et al. Cholecystokinin receptor imaging using an octapeptide DTPA-CCK analogue in patients with medullary thyroid carcinoma. European Journal of Nuclear Medicine 200027 1312-1317.

36 Behr TM, Jenner N, Radetzky S, Behe M, Gratz S, Yucekent S et al. Targeting of cholecystokinin-B/gastrin receptors in vivo: preclinical and initial clinical evaluation of the diagnostic and therapeutic potential of radiolabelled gastrin. European Journal of Nuclear Medicine 199825 424-430.

37 Behr TM, Jenner N, Behe M, Angerstein C, Gratz S, Raue F et al. Radiolabeled peptides for targeting cholecystokinin-B/gastrin receptor-expressing tumors. Journal of Nuclear Medicine $1999 \mathbf{4 0}$ 1029-1044.

38 Modlin IM \& Tang LH. The gastric enterochromaffin-like cell: an enigmatic cellular link. Gastroenterology $1996111783-810$.

39 Koh TJ, Goldenring JR, Ito S, Mashimo H, Kopin AS, Varro A et al. Gastrin deficiency results in altered gastric differentiation and decreased colonic proliferation in mice. Gastroenterology 1997 113 1015-1025.

40 Langhans N, Rindi G, Chiu M, Rehfeld JF, Ardman B, Beinborn M et al. Abnormal gastric histology and decreased acid production in cholecystokinin-B/gastrin receptor-deficient mice. Gastroenterology $1997112280-286$.

41 Beinfeld MC, Haun RS, Allard LR \& Dixon JE. Regulation of cholecystokinin secretion from a rat medullary thyroid carcinoma cell line: role of calcium, cyclic nucleotides, glucocorticoids, neurotensin, and calcitonin gene-related peptide. Peptides 199213 545-550.

42 Poston GJ, Draviam EJ, Seitz PK, Rajaraman S, Alexander RW, Cooper CW et al. Expression of cholecystokinin forms by medullary thyroid cancer. International Journal of Cancer 1991 48 689-692.

Received 20 June 2001

Accepted 22 August 2001 